\title{
Single versus two-stage phalloplasty for transgender female-to-male patients: a systematic review of the literature
}

\author{
Maria T. Huayllani ${ }^{1} \wedge$, Daniel Boczar ${ }^{1}$, Humza Y. Saleem ${ }^{2}$, Gabriela Cinotto ${ }^{1}$, Francisco R. Avila ${ }^{1}$, \\ Oscar J. Manrique ${ }^{3}$, Pedro Ciudad ${ }^{4}$, Brian D. Rinker ${ }^{1}$, Antonio J. Forte ${ }^{1 \wedge}$ \\ ${ }^{1}$ Division of Plastic Surgery, ${ }^{2}$ Department of Surgery, Mayo Clinic, Jacksonville, Florida, USA; ${ }^{3}$ Division of Plastic Surgery, Mayo Clinic, Rochester, \\ Minnesota, USA; ${ }^{4}$ Department of Plastic, Reconstructive and Burn Surgery, Arzobispo Loayza National Hospital, Lima, Peru \\ Contributions: (I) Conception and design: AJ Forte, MT Huayllani; (II) Administrative support: AJ Forte; (III) Provision of study materials or patients: \\ None; (IV) Collection and assembly of data: MT Huayllani, D Boczar; (V) Data analysis and interpretation: MT Huayllani, HY Saleem, G Cinotto, \\ FR Avila, OJ Manrique, P Ciudad, BD Rinker; (VI) Manuscript writing: All authors; (VII) Final approval of manuscript: All authors. \\ Correspondence to: Antonio J. Forte, MD, PhD, MS. Department of Surgery, Mayo Clinic, 4500 San Pablo Rd., Jacksonville, FL 32224, USA. \\ Email: ajvforte@yahoo.com.br.
}

\begin{abstract}
Phalloplasty is the main treatment for gender dysphoria disorder. It is difficult to ascertain if staging of phalloplasty influences the rate of complications. We aim to describe and compare the rates of complication between single versus two-stage phalloplasty for transgender female-to-male patients. PubMed, Ovid Medline, EMBASE and SCOPUS databases were queried for studies reporting complications of female-to-male transgender patients who underwent phalloplasty. The keywords "phalloplasty", "female to male", "outcome", "complication" and synonyms in different combinations were used for the search. Only studies that could identify whether phallic shaft creation was performed in a single or twostage procedure were included. From a total of 336 articles, 20 met the inclusion criteria. Sixteen studies reported complications associated with a single-stage phalloplasty and seven studies identified complications after a two-stage procedure. The most common complications found for both groups of staging were fistula, stricture and total/partial flap necrosis. Patients who underwent two-stage phalloplasty had higher complication rates (partial or total flap necrosis and fistulas), compared with the single-stage procedure $(\mathrm{P}<0.05)$. In conclusion, this systematic review identified the impact of staging in the rate of complications related to phalloplasty for transgender female-to-male patients; a two-stage phalloplasty has a higher rate of complications.
\end{abstract}

Keywords: Phalloplasty; transgender; female-to-male; staging; complication

Submitted May 06, 2020. Accepted for publication Nov 09, 2020.

doi: 10.21037/atm-20-3514

View this article at: http://dx.doi.org/10.21037/atm-20-3514

\section{Introduction}

Phalloplasty is a reconstructive procedure that involves the creation of a penis-like structure and is used in the treatment for gender dysphoria in trans female-to-male patients (1). Patients that have undergone penectomy for reasons other than sex-reassignment surgery can also benefit from phalloplasty. In fact, the first phallus reconstruction was performed by Bogoraz in 1936 in a patient who suffered a traumatic penectomy, using a pedicled tube graft of the abdominal skin and a piece of rib cartilage to give rigidity to the new organ (2). Currently, the radial artery free flap is the most common flap used for total phallic reconstruction (3).

^ ORCID: Maria T. Huayllani, 0000-0003-2690-1635; Antonio J. Forte, 0000-0003-2004-7538. 
Phalloplasty is also performed after penectomy due to several types of cancers. Epithelial cancers (e.g., squamous cell carcinoma) of stages $\mathrm{T} 1, \mathrm{~T} 2$, or $\mathrm{T} 3$ require total or partial glansectomy with reconstruction, wide local excision or partial penectomy with reconstruction, or total penectomy, respectively (3). Additionally, invasive urethral cancer is also treated with total penectomy (4). Penectomy has also been described as part of the treatment of some rare non-epithelial cancer types such as primitive neuroectodermal tumor or epithelioid sarcomas $(5,6)$. Therefore, phalloplasty is performed as part of a comprehensive surgical treatment for genital cancers. Besides patients undergoing sex-reassignment surgery and those with cancer, trauma patients, those with disorders of sexual development, and those with congenital anomalies (e.g., bladder exstrophy) have also benefited from these surgical techniques $(3,7,8)$.

The goal of any phalloplasty is to replicate the aesthetics of a penis while maintaining the functional ability for standing micturition and sexual intercourse (9). This surgery consists of a combination of sub-procedures such as the phallic shaft creation, the penile urethroplasty, the perineal urethroplasty, perineoplasty, scrotoplasty, vaginectomy, hysterectomy and oophorectomy, glansplasty, and colocation of the testicular implants and an erectile device (1). Multiple techniques for phalloplasty included the metoidioplasty as well as the use of different kind of flaps for the creation of the penile shaft such as the abdominal flaps, latissimus dorsi flaps, groin flaps, gracilis flaps, anterolateral thigh flaps, fibula flaps or radial forearm flaps (1). Metoidioplasty consists in the induction of clitoridean hypertrophy after the use of systemic testosterone (10-12). When performing metoidioplasty, the urethroplasty is done through a vaginal epithelial flap (13) or a combined buccal mucosal graft with labia minora flap (10). On the other hand, when utilizing the other flaps, multiple subprocedures are performed to allow flap insertion. First, the clitoris is de-epithelialized and translocated inferiorly to the pubic symphysis to allow the placement of the penile shaft and neourethra. After that, the urethroplasty is performed using a U-shaped or ring flap from the labia minora (14). The scrotoplasty is performed by the elevation and rotation of the labia majora flap, followed by the glansplasty. The procedure continues with the vascular and nerve anastomosis of the neophallus flap. Finally, the neophallus can be completely inset. Depending on the technique and the patients' preference, the colocation of testicular implants and an erectile device can be performed once the soft tissue reconstruction has healed (1). From all these subprocedures, creation of the phallic shaft and penile urethroplasty is the most critical step. There is a lack of consensus regarding the best technique and whether staging should be performed for phallic shaft creation and penile urethroplasty $(15,16)$. Staging a phalloplasty has been described in order to increase aesthetic outcomes and decrease complications (17). However, due to the complexity of the procedure, multiple definitions regarding staging have been established over the years (14). The most common definition of a singlestage phalloplasty is the combination of the urologic and microsurgical portion of the procedure including the phallic shaft creation, full-length urethroplasty, glansplasty, perineal reconstruction, vaginectomy and scrotoplasty without implant insertion (14). A two-stage procedure includes the placement of penile and/or testicular prostheses 9 to 12 months later (14). Nevertheless, the urethroplasty alone can be performed in a single-stage versus a two-stage approach, depending whether the perineal urethra and the shaft urethra happen in the same surgery or in different time points (17). In general, a two-stage phalloplasty independently of the component of the procedure involved, waits for the reaffirmation of the phallic tissue and concludes with the perineal masculinization divided in two surgeries performed in two different time points (18).

Several complications after performing a phalloplasty have been reported, these include urethrocutaneous fistulas, strictures, infections, hematomas and additional graft and flap complications $(14,17,19)$. The management of these complications depends on the area involved (1). Urethrocutaneous fistulas are the most complication of phalloplasty with a range incidence from $15 \%$ to $70 \%$ (20). They are more commonly located in the proximal urethral anastomosis between the phallic urethra and the fixed urethra and between the fixed urethra and the native urethra $(19,21)$. These fistulas are treated first through observation as spontaneous closure of the fistula occurs in up to $36 \%$ of patients within the 2 months of diagnosis (22). Fistulas that are present for more than 3 months can be treated through a suprapubic catheter and delayed stricture in cases in which a distal stricture is present or through a delayed surgical excision once the fistula tract has epithelialized and matured (1). Urethral strictures occur more commonly in areas with poor blood flow due to ischemia such as the anastomotic sites $(21,23-25)$. The first-line treatment recommended for these cases is endoscopic dilation especially for short and single strictures (26). Definitive treatment is accomplished with urethroplasty through a staged procedure with buccal 
graft or direct repair (1). Infections are usually noticed along the suture lines and are easily identified responding well to first generation of cephalosporins (1). Hematomas commonly appear in labial structures due to the formation of a dead space and the prone to bleed. To avoid the formation of hematomas, suprapubic and groin drains are placed along with compression over the bilateral labia majora (1). Heston et al. (18) also recommend the use of fibrin glue when performing the neurorrhaphy of the nerves to generate additional hemostasis. Other complications such as full or partial flap loss can also develop needing debridement of devitalized tissues, control of infection, and further reconstruction with grafts, dermal substitutes or secondary wound healing (1). To date, staging of phalloplasty remains a controversial topic and whether it has any utility in influencing the rate of complications. The purpose of this study is to review, summarize and compare the percentage of complications between a single and twostage phalloplasty in transgender female-to-male patients. We present the following article in accordance with the PRISMA reporting checklist (available at http://dx.doi. org/10.21037/atm-20-3514).

\section{Methods}

\section{Study selection}

Our systematic review included all studies evaluating the phallic shaft creation for transgender female-to-male patients in a single and two-stage procedure following the PRISMA (Preferred Reporting Items for Systematic Reviews and Meta-Analyses) guidelines for article identification and final selection. Studies were included if a single or two-stage procedure was identified for the phallic shaft creation with description of the most common complications. Studies were excluded if they only reported results related with other steps different than shaft creation for phalloplasty, did not report complications, described a new operative technique, were case reports, not written in English or specify whether a single or two-staged procedure was performed.

\section{Data sources and search strategy}

This systematic review was conducted by one author (MT Huayllani) on January 16, 2019, by querying the PubMed, Ovid Medline, EMBASE and SCOPUS databases. A search strategy was generated using the following terms:
("phalloplasty"[Title/Abstract] OR "neophallus"[Title/ Abstract]) AND (("female to male"[Title/Abstract]) OR ("female to male/gender"[Title/Abstract])) AND (("outcomes"[Title/Abstract]) OR ("complication"[Title/ Abstract]) OR ("outcome"[Title/Abstract]) OR ("complications"[Title/Abstract])). Identified studies were uploaded into EndNote (Clarivate). Two independent reviewers (MT Huayllani and D Boczar) selected the final studies. Manuscripts were first screened manually by one author (MT Huayllani) and selected according to inclusion and exclusion criteria. First, studies were reviewed based on the title and abstract. Second, the full text of the selected studies was screened for the final selection. If there were questionable articles to include, the second reviewer (D Boczar) revised these articles according to selection criteria, and both reviewers came to an agreement for the final decision.

\section{Quality assessment}

The level of evidence and the quality of each publication was evaluated by the reviewers using the Oxford Center for Evidence-Based Medicine and the Newcastle-Ottawa Scale, respectively. All manuscripts were cohort studies and most of them had a Newcastle-Ottawa Scale scored 6 out of 9 . Twelve studies (10-12,15,27-35) lost three points (one point in selection and two points for comparability) due to lack of a comparative group; two $(13,27)$ lost two points (only in comparability) due to lack of adjustment of risk factors; and six $(27,36-40)$ lost two additional points due to no statement of follow-up (Table 1).

\section{Data pooling}

All the data was pooled and summarized. Author, year of publication, number of participants, age, follow-up, stages for phallic shaft creation, and graft/flap used in the procedure of included studies were presented.

\section{Statistical analysis}

The total number of patients and the percentage of complications were compiled for the included studies and compared between single and two-stage procedures using Chi-square $\left(\chi^{2}\right)$ and Fisher test analyses. A value of $\mathrm{P}<0.05$ was considered statistically significant. SPSS, version 25 (SPSS, Inc., an IBM Company, Chicago, Illinois, USA) software was used to perform the analysis. 
Table 1 Articles to date that assess the single stage and two stage procedure of phalloplasty in transgender female-to-male patients

\begin{tabular}{|c|c|c|c|c|c|c|c|c|}
\hline Author & Year & $\begin{array}{l}\text { OCEBM } \\
\text { level of } \\
\text { evidence }\end{array}$ & $\begin{array}{l}\text { Quality } \\
\text { (Newcastle- } \\
\text { Ottawa Scale) }\end{array}$ & $\begin{array}{l}\text { Number of } \\
\text { patients }\end{array}$ & Age (years) & Follow-up & Stages & Graft/flap/procedure \\
\hline Fang et al. (36) & & & & & & & Two stages & $\begin{array}{l}\text { Vaginal mucosa tube graft } \\
\text { and radial forearm flap }\end{array}$ \\
\hline \multirow[t]{2}{*}{$\begin{array}{l}\text { Bettocchi et al. } \\
\text { (27) }\end{array}$} & 2005 & 3 & 5 & 85 & $\begin{array}{l}\text { Mean: } 34.4 \\
\text { (range, 19-54) }\end{array}$ & - & Single stage & $\begin{array}{l}\text { Anterior abdominal wall skin } \\
\text { flap }\end{array}$ \\
\hline & & & & & & & Two stages & $\begin{array}{l}\text { Anterior abdominal wall skin } \\
\text { flap }\end{array}$ \\
\hline $\begin{array}{l}\text { Vesely et al. } \\
\text { (28) }\end{array}$ & 2007 & 3 & 6 & 22 & $\begin{array}{l}\text { Mean: } 28.6 \\
\text { (range, 24-38) }\end{array}$ & $\begin{array}{l}\text { Mean: } 23.9 \\
\text { (range, 11-44) } \\
\text { months }\end{array}$ & Single stage & $\begin{array}{l}\text { Latissimus dorsi } \\
\text { myocutaneous free flap }\end{array}$ \\
\hline $\begin{array}{l}\text { Leriche et al. } \\
\text { (29) }\end{array}$ & 2008 & 3 & 6 & 56 & $\begin{array}{l}\text { Mean: } 30 \\
\text { (range, 20-44) }\end{array}$ & $\begin{array}{l}\text { Mean: } 110 \\
\text { (range, 11-204) } \\
\text { months }\end{array}$ & Single stage & Free radial forearm flap \\
\hline $\begin{array}{l}\text { Lumen et al. } \\
(30)\end{array}$ & 2008 & 3 & 6 & 7 & Range, 15-42 & $\begin{array}{l}\text { Range, 9-34 } \\
\text { months }\end{array}$ & Single stage & $\begin{array}{l}\text { Free radial forearm flap or } \\
\text { anterolateral thigh flap }\end{array}$ \\
\hline $\begin{array}{l}\text { Djordjevic et al. } \\
\text { (10) }\end{array}$ & 2009 & 3 & 6 & 82 & $\begin{array}{l}\text { Mean: } 31 \\
\text { (range, 18-54) }\end{array}$ & $\begin{array}{l}\text { Mean: } 32 \\
\text { (range, 14-69) } \\
\text { months }\end{array}$ & Single stage & $\begin{array}{l}\text { Buccal mucosa graft/genital } \\
\text { flaps/Metoidioplasty }\end{array}$ \\
\hline $\begin{array}{l}\text { Garaffa et al. } \\
(32)\end{array}$ & 2010 & 3 & 6 & 115 & $\begin{array}{l}\text { Median: } 34.9 \\
\text { (range, 20-55) }\end{array}$ & $\begin{array}{l}\text { Median: } 26 \\
\text { (range, } 1-270) \\
\text { months }\end{array}$ & Two stages & $\begin{array}{l}\text { Free radial forearm flap and } \\
\text { local labial and anterior } \\
\text { vaginal flaps }\end{array}$ \\
\hline $\begin{array}{l}\text { Garaffa et al. } \\
\text { (33) }\end{array}$ & 2010 & 3 & 6 & 27 & $\begin{array}{l}\text { Median: } 40.4 \\
\text { (range, 30-55) }\end{array}$ & $\begin{array}{l}\text { Median: } 9.2 \\
\text { (range, 1-32) } \\
\text { months }\end{array}$ & Two stages & $\begin{array}{l}\text { Free radial forearm flap and } \\
\text { vaginal mucosa tube graft }\end{array}$ \\
\hline $\begin{array}{l}\text { Djordjevic et al. } \\
\text { (12) }\end{array}$ & 2013 & 3 & 6 & 207 & $\begin{array}{l}\text { Mean: } 32 \\
\text { (range, 18-62) }\end{array}$ & $\begin{array}{l}\text { Median: } 39 \\
\text { (range, 12-118) } \\
\text { months }\end{array}$ & Single stage & $\begin{array}{l}\text { Buccal mucosa graft/genital } \\
\text { flaps/metoidioplasty }\end{array}$ \\
\hline $\begin{array}{l}\text { Vukadinovic } \\
\text { et al. (34) }\end{array}$ & 2014 & 3 & 6 & 97 & Range, 18-41 & $\begin{array}{l}\text { Range, 13-69 } \\
\text { months }\end{array}$ & Single stage & $\begin{array}{l}\text { Buccal mucosa graft/genital } \\
\text { flaps/metoidioplasty }\end{array}$ \\
\hline $\begin{array}{l}\text { Zhang et al. } \\
\text { (39) }\end{array}$ & 2015 & 3 & 4 & 22 & $\begin{array}{l}\text { Mean: } 27.8 \\
\text { (range, 19-34) }\end{array}$ & - & Two stages & $\begin{array}{l}\text { Pedicled-flap phalloplasty or } \\
\text { anterolateral thigh flap }\end{array}$ \\
\hline
\end{tabular}

Table 1 (continued) 
Table 1 (continued)

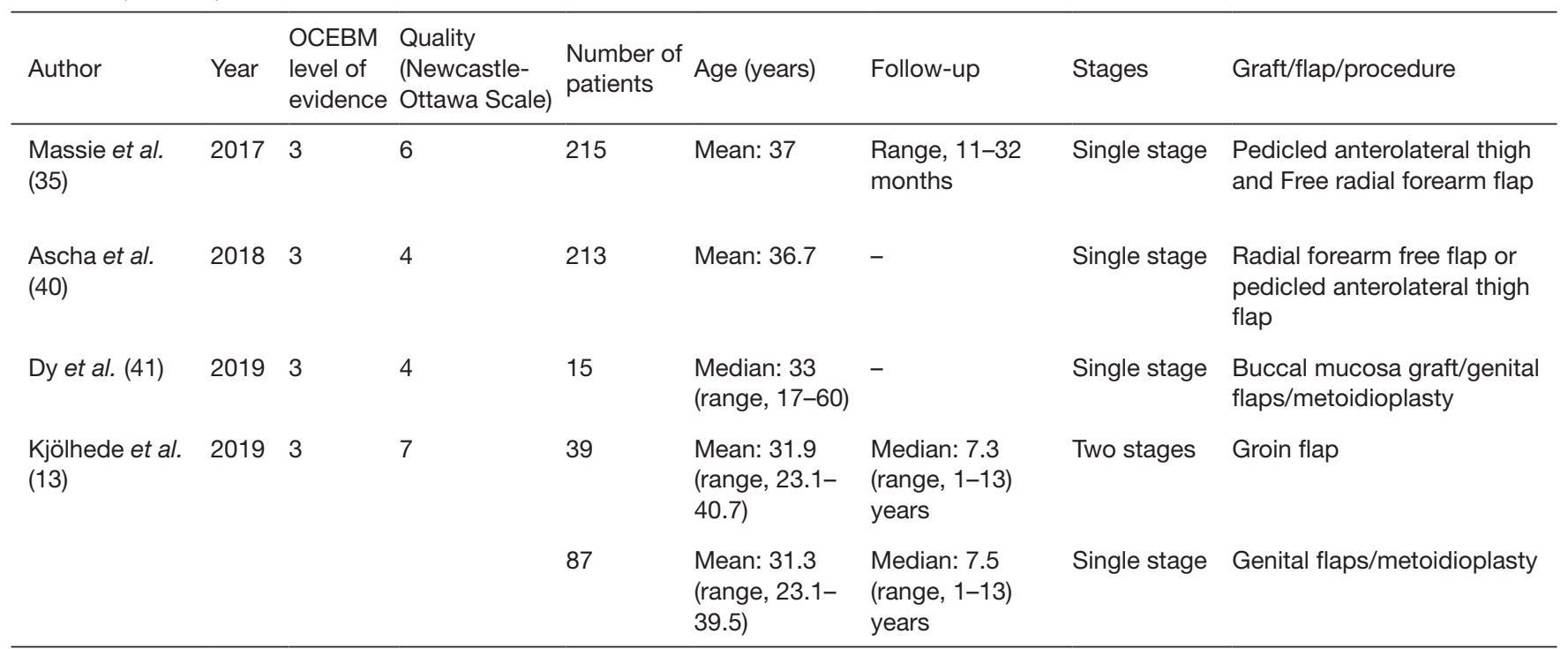

OCEBM, Oxford Center for Evidence-Based Medicine.

\section{Results}

\section{Included studies}

Initial search demonstrated 71,53,138 and 74 articles in PubMed, Ovid Medline, EMBASE and SCOPUS, respectively, from which only 20 met inclusion criteria (Figure 1). All included studies were published between 1994 and 2019. Table 1 demonstrates Study descriptions. Sixteen studies (10-13,27-31,34-38,40,41) reported the complications associated with a single-stage phalloplasty and seven studies $(13,15,27,32,33,36,39)$ identified those complications after a two-stage procedure. A total of 1,638 patients were considered in the analysis. From these, 1,352 $(82.5 \%)$ underwent a single-stage phalloplasty while a total of $286(17.5 \%)$ underwent a two-stage procedure.

\section{Patients' characteristics}

The age of patients ranged from 15 to 62 years. The followup between studies ranged from 1 to 168 months. The flaps used for phallic shaft creation included free radial forearm flap, lateral groin flap, anterior abdominal wall skin flap, anterolateral thigh flap, latissimus dorsi myocutaneous free flap, the pedicled-flap phalloplasty, pedicled anterolateral, groin flap, thigh flap, and the flaps utilized for metoidioplasty.

\section{Complications}

The most common complications reported between the studies were partial or total flap necrosis, the partial or total flap loss, fistulas, stricture, infection, and hematomas (Table 2). When comparing the percentage of complications between single and two-stage phalloplasty, we found that partial/total flap necrosis $\left(5.9 \%\right.$ versus $1.3 \% ; \chi^{2}, 25.509$; $\mathrm{P}<0.001)$ and fistulas $\left(20.6 \%\right.$ versus $15.7 \% ; \chi^{2}, 4.187$; $\mathrm{P}=0.041)$ were more prevalent after two-stage procedure, compared to a single procedure (Figure 2). No statistical difference between staging of procedure and complications such as partial/total flap loss, strictures, infection and hematoma.

\section{Discussion}

Reconstruction of the phallus aims to retain or restore the ability to urinate while standing, achieve erection and sexual penetration, and maintain an erogenous sensation to the phallus or neophallus (3).

Regarding the functional outcomes after phalloplasty, Frey et al. (42) found that, out of all evaluated patients that underwent phalloplasty using the radial artery free flap technique as part of the sex-reassignment process, $70 \%$ were satisfied with the aesthetic outcome, $69 \%$ recovered the erogenous sensation, $43 \%$ reported successful penetration, 


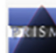

PRISMA 2009 Flow Diagram
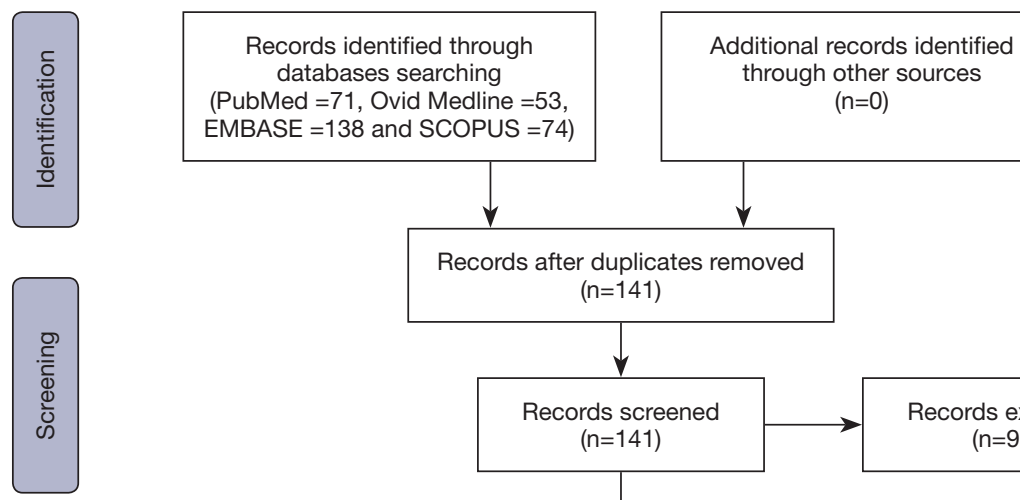

Records after duplicates removed $(n=141)$
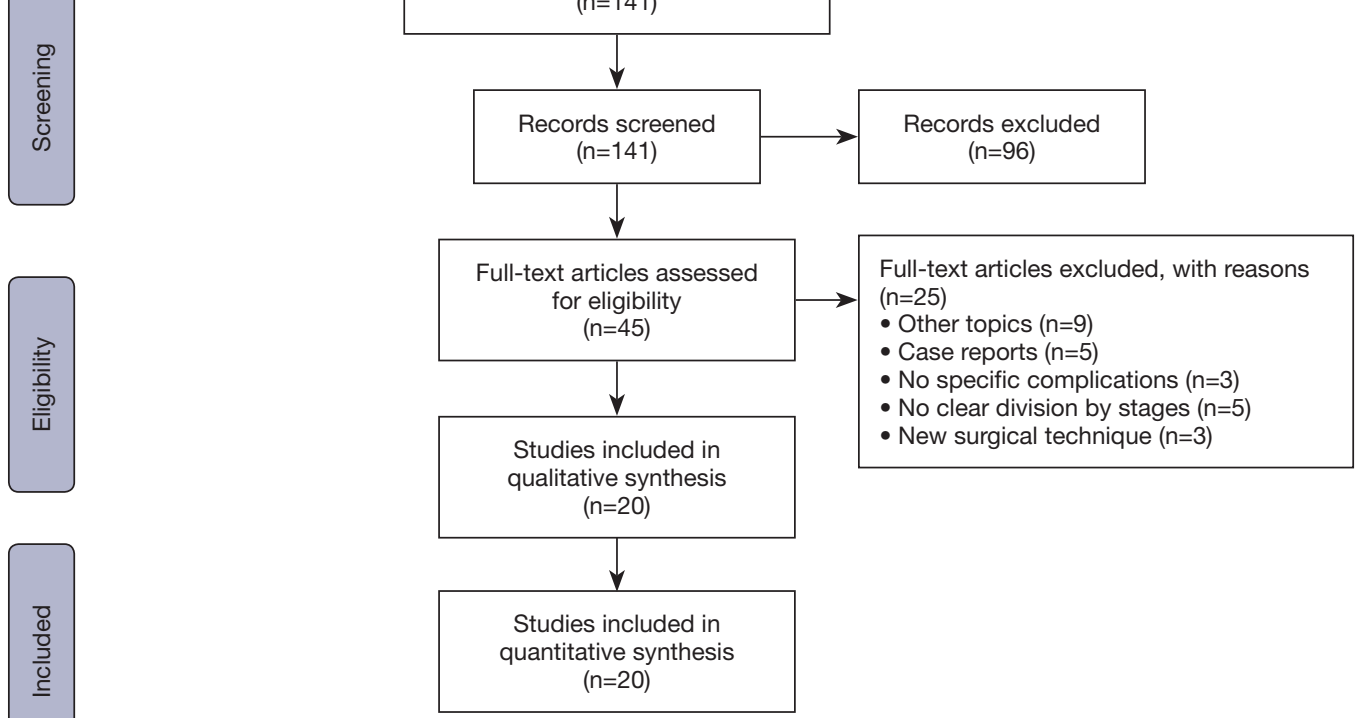

Figure 1 Inclusion and exclusion criteria.

and $89 \%$ achieved standing micturition (42). Moreover, Callens et al. (43) found that patients diagnosed micropenis who had underwent phalloplasty had higher satisfaction with the surgical results than those that had genital surgery without phalloplasty, and pointed that studies with longer follow-up periods are needed to correctly assess improvements in physical and sexual outcomes (43). In a recent systematic review by Morrison et al. (44), the authors found that recovery of general glans sensitivity after phalloplasty occurred in $>70 \%$ of cis-male patients and in $>90 \%$ of trans-male patients, while erogenous sensibility was recovered by $>75 \%$ of cis-male patients and by $>95 \%$ of trans-male patients (44). The authors stated that this discrepancy in sensibility recovery rates might be owed to different nerve coaptations during the surgical procedures. For example, certain surgeons preferred to leave a fully functional clitoris under the neo-phallus to improve erogenous sensitivity in trans-male patients (44).
Of note, few of the articles reviewed by Morrison et al. used standardized measurements of sensitivity (44).

In addition, Garaffa et al. (45) reported excellent functional outcomes in their 15 -cancer patient case series using radial artery free flaps. After a mean follow-up period of 20 months (1-68 months) all patients were able to void while standing, complete sensation was reported in 12 out of 15 patients, and all patients were satisfied with size and cosmetic result (45). Additionally, out of the seven patients that had a penile prosthesis inserted, five had resumed sexual activity at follow-up (45). Elhaggagy et al. (8) reported satisfactory sensitive, cosmetic, and voiding outcomes for 9 male pseudohermaphrodite patients in which the radial artery free flap was used to treat sequels of penile mutilation after gender misdiagnosis and attempted female circumcision (8). However, erogenous sensibility could not be assessed (8).

On the other hand, Akino et al. (5) reported a case of a 
Table 2 Percentage of complications for single-stage and two-stage procedure of phalloplasty in transgender female-to-male patients

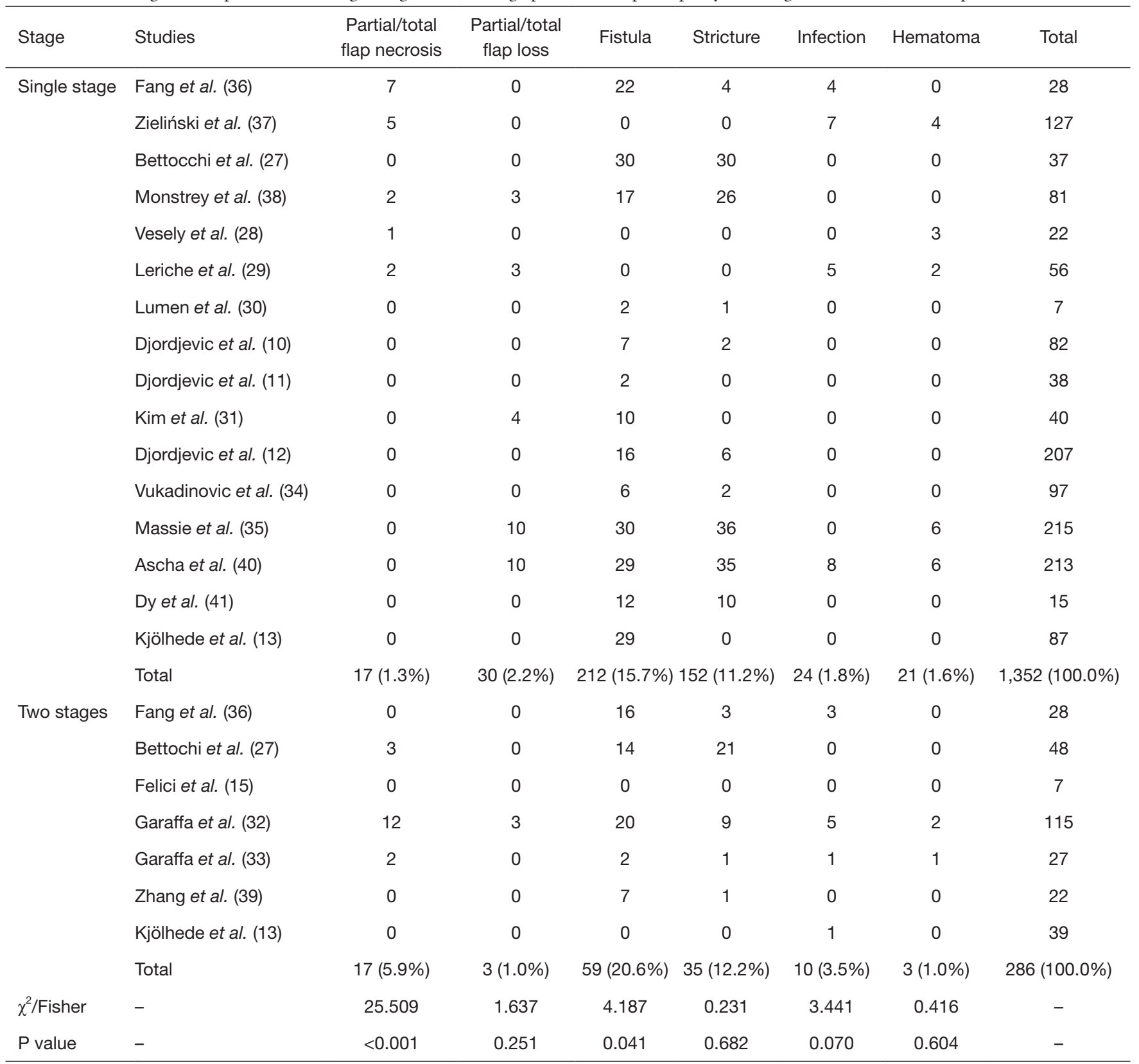

16-year-old boy with primitive neuroectodermal tumor who underwent total penectomy and chemotherapy with radial artery free flap phalloplasty 1 year after the first surgical procedure (5). Favorable cosmetic, urinary, and sexual outcomes were reported seven years after the reconstruction surgery (5). Another case of penile cancer in a child was presented by Hoebeke et al. (6), who reported a case of a 16-year-old boy with an epithelioid sarcoma who underwent total penectomy without chemotherapy. Contrary to the last case, phalloplasty was performed immediately after penectomy. Regarding functional outcomes, the authors report that voiding restarted after post-surgical day 12 . The patient was satisfied with the outcome and cosmetic results were favorable (6).

There are a wide variety of non-standardized surgical techniques to accomplish the goal of phalloplasty for 


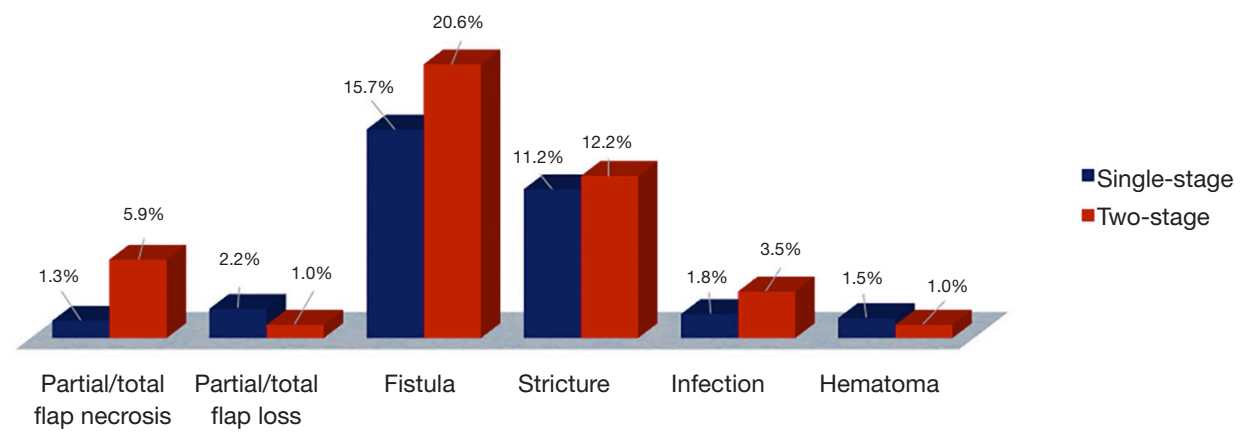

Figure 2 Graphic bar of complications by staging of phalloplasty.

transgender female-to-male patients. This systematic review sought to compare the frequency of complications between a single and two-stage phalloplasty independently of the different flaps harvesting applied. Our review found a higher frequency of fistulas and partial or total flap necrosis in patients who underwent a two-stage compared to a singlestage procedure. Remington et al. (46) demonstrated similar result, they analyzed the rate of complications between a single versus a staged urethroplasty by performing a systematic review comparing transmale and cismale patients. They found a higher complication rate in patients who underwent staged urethroplasty procedures $(34.8 \%)$ compared with those who had a primary urethroplasty (31.3\%) (46). Complications secondary to phalloplasty are a well-known barrier to achieving good outcomes (23). Division of stages for phalloplasty could be a contributor to higher complication rates due to the use of combined surgical procedures that usually involve more than one flap and increase the morbidity related to harvested tissues $(33,39)$. This explanation is based on the variability of flaps used for phalloplasty between the included studies. The two-stage procedure, in some studies, consisted first with prefabrication of the urethra with full thickness vaginal mucosa and tube formation of this graft, followed by a second stage for the harvesting of a radial forearm flap (36), pedicled abdominal flap or anterolateral thigh flap (39) with subsequent creation and fixation of the neophallus to the pubic region. Similarly, other studies report complications of a two-stage procedure, in which phalloplasty was divided according to the creation of phallic shaft urethra. This means that the first stage consisted in the formation of the phallic shaft urethra using the anterior abdominal wall skin flap (27), anterolateral thigh flap (15) or the free radial forearm flap (33) followed by a second stage of the anastomosis of the neourethra to the perineal periurethral

\section{$(15,27,33)$.}

Patients who underwent a single-stage phalloplasty were treated using one of the previously mentioned flaps for the phallic shaft creation and urethroplasty in one unique moment. In three studies $(11,12,34)$ metoidioplasty was considered also a single-stage method. Metoidioplasty consists of the creation of a neophallus from the clitoris after hormonal stimulation, removal of the female genitalia and detaching of the clitoral ligaments (42). This procedure uses the anterior vaginal wall for the urethral reconstruction and a longitudinal island flap from the dorsal clitoral or labia minora skin for the phallic shaft reconstruction (12).

The time between both stages for patients who underwent a two-stage phalloplasty might have influenced into the rate of complications, however all the second stages procedures were performed after at least 3 weeks of first stage which suggests that a good healing of the first wound was established and time was not likely a determinant of rate of complications.

Urethrocutaneous fistula was the most common complication, followed by the strictures for both single and two-stages procedures. Fistula rates ranged from $22 \%$ to $75 \%$ for radial free flap phalloplasty $(21,47)$ while stricture has an incidence ranging from $25 \%$ to $58 \%$ (21). The urethral fistulas and strictures when appear they are commonly located in the areas of anastomosis $(19,48)$. A less frequent but significantly important complication was the partial/total flap necrosis that had a higher incidence in a two-stage phalloplasty compared to the single-stage phalloplasty. The partial necrosis rate for a free forearm flap was $7.3 \%$ (20). This complication is often related to the positioning of the flap design, and for staged procedures, where the phallus is created before the urethral lengthening, delay in wound healing can predispose to flap necrosis (18).

A two-stage approach allows the work of plastic surgery 
and urology team to be performed separately, decreasing the time of surgery with benefits for surgeons and also for patients. Also, when performing a single-stage procedure, the flap transfer and the creation of a perineal urethra involves the formation of ischemic sites in the urethral repair which makes difficult the evaluation of the wound closure (17). On the other hand, when performing a twostage procedure the correct healing of the first procedure can be better established and corrected if any complication develops (17). However, we recommend assessing carefully the surgical technique that will be applied and to have an individual approach to evaluate benefit-risk balance for each patient.

Transgender patients who request a phalloplasty should be assessed by a multidisciplinary team and could also benefit from psychotherapy. The role of psychotherapy for patients with gender dysphoria is to explore gender identity, address the stigma and minority stress, ease the coming out process, treat co-existing mental health pathologies, confront internalized transphobia, and, lastly, to attain comfort and realization $(49,50)$. Although specific psychotherapy modalities to aid in this process are not described, affirmative approaches that explore and validate the positive expression of the individuals' identities are starting to be used in these patients due to the beneficial effects observed on homosexual and bisexual patients (51). These approaches are ways to enhance existing psychotherapy methods and are not meant to be used as independent treatment modalities. Additionally, psychotherapy often helps patients assimilate their transor cross-gender feelings into their assigned gender roles at birth, which may eliminate the need to modify their bodies (49).

\section{Strengths and limitations}

Limitations of our study included the heterogeneity of the studies and the variations of operative techniques applied for phalloplasty amongst different surgeons. These were addressed by using a strict inclusion and exclusion criteria. This systematic review only included studies with wellestablished flap techniques for phallic shaft creation and urethroplasty. In addition, inherent limitations of the review methodology due search, selection, and publication biases were present. However, we believe this reported data is valuable, as it compared the impact of staging procedures in the rate of complications after a phalloplasty performed for transgender female-to-male patients.

\section{Conclusions}

In conclusion, two-stage phalloplasty has greater rate of complications such as urethrocutaneous fistulas and total/partial flap necrosis when compared to a singlestage phalloplasty. Further studies should be conducted to establish the factors associated with these complications to ultimately determine the best management for transgender female-to-male patients.

\section{Acknowledgments}

Funding: This study was supported in part by the Mayo Clinic Center for Individualized Medicine and the Center for Regenerative Medicine; and the Plastic Surgery Foundation.

\section{Footnote}

Provenance and Peer Review: This article was commissioned by the editorial office, Annals of Translational Medicine for the series "Transgender Surgery". The article has undergone external peer review.

Reporting Checklist: The authors have completed the PRISMA reporting checklist. Available at http://dx.doi. org/10.21037/atm-20-3514

Conflicts of Interest: All authors have completed the ICMJE uniform disclosure form (available at http://dx.doi. org/10.21037/atm-20-3514). The series "Transgender Surgery" was commissioned by the editorial office without any funding or sponsorship. OJM served as the unpaid Guest Editor of the series. The other authors have no other conflicts of interest to declare.

Ethical Statement: The authors are accountable for all aspects of the work in ensuring that questions related to the accuracy or integrity of any part of the work are appropriately investigated and resolved.

Open Access Statement: This is an Open Access article distributed in accordance with the Creative Commons Attribution-NonCommercial-NoDerivs 4.0 International License (CC BY-NC-ND 4.0), which permits the noncommercial replication and distribution of the article with the strict proviso that no changes or edits are made and the original work is properly cited (including links to both the 
formal publication through the relevant DOI and the license). See: https://creativecommons.org/licenses/by-nc-nd/4.0/.

\section{References}

1. Morrison SD, Shakir A, Vyas KS, et al. Phalloplasty: A Review of Techniques and Outcomes. Plast Reconstr Surg 2016;138:594-615.

2. Schultheiss D, Gabouev AI, Jonas U. Nikolaj A. Bogoraz (1874-1952): pioneer of phalloplasty and penile implant surgery. J Sex Med 2005;2:139-46.

3. Bickell M, Beilan J, Wallen J, et al. Advances in Surgical Reconstructive Techniques in the Management of Penile, Urethral, and Scrotal Cancer. Urol Clin North Am 2016;43:545-59.

4. Ishii T, Hiratsuka Y, Abe H, et al. Subcutaneous penectomy and phalloplasty using a testicle for invasive urethral carcinoma. J Urol 2002;167:248.

5. Akino T, Shinohara N, Hatanaka K, et al. Successful penile reconstruction after multimodal therapy in patients with primitive neuroectodermal tumor originating from the penis. Int J Urol 2014;21:619-21.

6. Hoebeke PB, Rottey S, Van Heddeghem N, et al. Onestage penectomy and phalloplasty for epithelioid sarcoma of the penis in an adolescent. Eur Urol 2007;51:1429-32.

7. Sarıkaya S, Ralph DJ. Mystery and realities of phalloplasty: a systematic review. Turk J Urol 2017;43:229-36.

8. Elhaggagy A, Elgammal M, Gadelmoula $M$, et al. Phalloplasty for an amputated phallus in intersex patients. Arab J Urol 2012;10:382-7.

9. Hage JJ, Bout CA, Bloem JJ, et al. Phalloplasty in femaleto-male transsexuals: what do our patients ask for? Ann Plast Surg 1993;30:323-6.

10. Djordjevic ML, Stanojevic D, Bizic M, et al. Metoidioplasty as a single stage sex reassignment surgery in female transsexuals: Belgrade experience. J Sex Med 2009;6:1306-13.

11. Djordjevic ML, Bizic M, Stanojevic D, et al. Urethral Lengthening in metoidioplasty (female-to-male sex reassignment surgery) by combined buccal mucosa graft and labia minora flap. Urology 2009;74:349-53.

12. Djordjevic ML, Bizic MR. Comparison of two different methods for urethral lengthening in female to male (metoidioplasty) surgery. J Sex Med 2013;10:1431-8.

13. Kjölhede A, Cornelius F, Huss F, et al. Metoidioplasty and groin flap phalloplasty as two surgical methods for the creation of a neophallus in female-to-male genderconfirming surgery: A retrospective study comprising 123 operated patients. JPRAS Open 2019;22:1-8.

14. Chen ML, Safa B. Single-Stage Phalloplasty. Urol Clin North Am 2019;46:567-80.

15. Felici N, Felici A. A new phalloplasty technique: the free anterolateral thigh flap phalloplasty. J Plast Reconstr Aesthet Surg 2006;59:153-7.

16. Morrison SD, Perez MG, Carter CK, et al. Pre- and Post-Operative Care With Associated Intra-Operative Techniques for Phalloplasty In Female-to-Male Patients. Urol Nurs 2015;35:134-8.

17. Danker S, Esmonde N, Berli JU. "Staging" in Phalloplasty. Urol Clin North Am 2019;46:581-90.

18. Heston AL, Esmonde NO, Dugi DD 3rd, et al. Phalloplasty: techniques and outcomes. Transl Androl Urol 2019;8:254-65.

19. Blaschke E, Bales GT, Thomas S. Postoperative imaging of phalloplasties and their complications. AJR Am J Roentgenol 2014;203:323-8.

20. Monstrey S, Hoebeke P, Selvaggi G, et al. Penile reconstruction: is the radial forearm flap really the standard technique? Plast Reconstr Surg 2009;124:510-8.

21. Rohrmann D, Jakse G. Urethroplasty in female-to-male transsexuals. Eur Urol 2003;44:611-4.

22. Fang RH, Kao YS, Ma S, et al. Phalloplasty in female-tomale transsexuals using free radial osteocutaneous flap: a series of 22 cases. Br J Plast Surg 1999;52:217-22.

23. Morrison SD, Chen ML, Crane CN. An overview of female-to-male gender-confirming surgery. Nat Rev Urol 2017;14:486-500.

24. Monstrey SJ, Ceulemans P, Hoebeke P. Sex Reassignment Surgery in the Female-to-Male Transsexual. Semin Plast Surg 2011;25:229-44.

25. Levine LA, Elterman L. Urethroplasty following total phallic reconstruction. J Urol 1998;160:378-82.

26. Lumen N, Oosterlinck W, Decaestecker K, et al. Endoscopic incision of short $(<3 \mathrm{~cm})$ urethral strictures after phallic reconstruction. J Endourol 2009;23:1329-32.

27. Bettocchi C, Ralph DJ, Pryor JP. Pedicled pubic phalloplasty in females with gender dysphoria. BJU Int 2005;95:120-4.

28. Vesely J, Hyza P, Ranno R, et al. New technique of total phalloplasty with reinnervated latissimus dorsi myocutaneous free flap in female-to-male transsexuals. Ann Plast Surg 2007;58:544-50.

29. Leriche A, Timsit MO, Morel-Journel N, et al. Long-term outcome of forearm flee-flap phalloplasty in the treatment of transsexualism. BJU Int 2008;101:1297-300.

30. Lumen N, Monstrey S, Selvaggi G, et al. Phalloplasty: 
a valuable treatment for males with penile insufficiency. Urology 2008;71:272-6; discussion 276-7.

31. Kim SK, Lee KC, Kwon YS, et al. Phalloplasty using radial forearm osteocutaneous free flaps in femaleto-male transsexuals. J Plast Reconstr Aesthet Surg 2009;62:309-17.

32. Garaffa G, Christopher NA, Ralph DJ. Total phallic reconstruction in female-to-male transsexuals. Eur Urol 2010;57:715-22.

33. Garaffa G, Ralph DJ, Christopher N. Total urethral construction with the radial artery-based forearm free flap in the transsexual. BJU Int 2010;106:1206-10.

34. Vukadinovic V, Stojanovic B, Majstorovic M, et al. The role of clitoral anatomy in female to male sex reassignment surgery. ScientificWorldJournal 2014;2014:437378.

35. Massie JP, Morrison SD, Wilson SC, et al. Phalloplasty with Urethral Lengthening: Addition of a Vascularized Bulbospongiosus Flap from Vaginectomy Reduces Postoperative Urethral Complications. Plast Reconstr Surg 2017;140:551e-558e.

36. Fang RH, Lin JT, Ma S. Phalloplasty for female transsexuals with sensate free forearm flap. Microsurgery 1994;15:349-52.

37. Zieliński T. Phalloplasty using a lateral groin flap in female-to-male transsexuals. Acta Chir Plast 1999;41:15-9.

38. Monstrey S, Hoebeke P, Dhont M, et al. Radial forearm phalloplasty: A review of 81 cases. Eur J Plast Surg 2005;28:206-12.

39. Zhang YF, Liu CY, Qu CY, et al. Is vaginal mucosal graft the excellent substitute material for urethral reconstruction in female-to-male transsexuals? World J Urol 2015;33:2115-23.

40. Ascha M, Massie JP, Morrison SD, et al. Outcomes of Single Stage Phalloplasty by Pedicled Anterolateral Thigh Flap versus Radial Forearm Free Flap in Gender Confirming Surgery. J Urol 2018;199:206-14.

41. Dy GW, Granieri MA, Fu BC, et al. Presenting Complications to a Reconstructive Urologist After

Cite this article as: Huayllani MT, Boczar D, Saleem HY, Cinotto G, Avila FR, Manrique OJ, Ciudad P, Rinker BD, Forte AJ. Single versus two-stage phalloplasty for transgender female-to-male patients: a systematic review of the literature. Ann Transl Med 2021;9(7):608. doi: 10.21037/atm-20-3514
Masculinizing Genital Reconstructive Surgery. Urology 2019;132:202-6.

42. Frey JD, Poudrier G, Chiodo MV, et al. A Systematic Review of Metoidioplasty and Radial Forearm Flap Phalloplasty in Female-to-male Transgender Genital Reconstruction: Is the "Ideal" Neophallus an Achievable Goal? Plast Reconstr Surg Glob Open 2016;4:e1131.

43. Callens N, De Cuypere G, Van Hoecke E, et al. Sexual quality of life after hormonal and surgical treatment, including phalloplasty, in men with micropenis: a review. J Sex Med 2013;10:2890-903.

44. Morrison SD, Massie JP, Dellon AL. Genital Sensibility in the Neophallus: Getting a Sense of the Current Literature and Techniques. J Reconstr Microsurg 2019;35:129-37.

45. Garaffa G, Raheem AA, Christopher NA, et al. Total phallic reconstruction after penile amputation for carcinoma. BJU Int 2009; 104:852-6.

46. Remington AC, Morrison SD, Massie JP, et al. Outcomes after Phalloplasty: Do Transgender Patients and Multiple Urethral Procedures Carry a Higher Rate of Complication?. Plast Reconstr Surg 2018;141:220e-229e.

47. Nikolavsky D, Yamaguchi Y, Levine JP, et al. Urologic Sequelae Following Phalloplasty in Transgendered Patients. Urol Clin North Am 2017;44:113-25.

48. Lumen N, Monstrey S, Goessaert AS, et al. Urethroplasty for strictures after phallic reconstruction: a singleinstitution experience. Eur Urol 2011;60:150-8.

49. Coleman E, Bockting W, Botzer M, et al. Standards of care for the health of transsexual, transgender, and gender-nonconforming people, version 7. Int J Transgend 2012;13:165-232.

50. Bockting W. Psychotherapy and the real-life experience: From gender dichotomy to gender diversity. Sexologies 2008;17:211-24.

51. Tozer EE, McClanahan MK. Treating the purple menace: Ethical considerations of conversion therapy and affirmative alternatives. Couns Psychols 1999;27:722-42. 